$16^{\text {th }}$ International Congress of Metrology, 10005 (2013)

DOI: $10.1051 /$ metrology/201310005

(C) Owned by the authors, published by EDP Sciences, 2013

\title{
Metrological study of typical Brazilian diesel
}

\author{
Mauricio G Fonseca ${ }^{1}$, Luciano N Batista ${ }^{1}$, Viviane F. Silva ${ }^{1}$, Erica C G Pissurno ${ }^{1}$, Thais C Soares ${ }^{1}$, Monique R Jesus ${ }^{1}$, \\ Paulo R M Silva ${ }^{1}$, Valnei S Cunha ${ }^{1}$ and Romeu J Daroda ${ }^{1}$.
}

\section{${ }^{1}$ INMETRO - National Institute of Metrology, Quality and Technology, 25250-020 Duque de Caxias, Rio de} Janeiro, Brasil.

\begin{abstract}
New alternative energy has been an interesting field for research and development in attempt to diminish the environmental imbalance that has occasioned several climatic changes occurred over the past decades. This research area has obtained a great advance in methodologies to produce alternative energies, where is possible to produce energy through alternative sources that usually are less polluting and are useful to replace the crude oil and petroleum derivatives. These alternative energy sources have become an important tool in the fight against pollution. Among some alternatives energy, stands out biodiesel an available alternative fuel, which is capable to diminish problems related to important areas as environmental and social development. From this point INMETRO, has developing, in line with the policy of the Brazilian government, studies to obtain alternative and renewable sources of energy as bioethanol and biodiesel. This work shows a methyl biodiesel short-time stability study in attempt to observe how much temperature can affect the biodiesel quality. Were used two methodologies to verify the biodiesel quality, the oxidative stability by Rancimat method and Iodine Index.
\end{abstract}

\section{Introduction}

The actual world is completely dependent of energy. Every section of the society needs energy to make easy, simple things as to work, for example. This dependence is related to keep every human been alive, as the equipment in the hospitals and is even related to study, the use of internet, notebooks, to connect people, batteries from cell phones, for example, the transports by plane or even by car or by ships, $i$ and even is related to work, is an important tool in the factories and even in the business centres in the modern world. Energy is also present in our houses, facilitating to cook, to watch tv and even to do something more usual and simple as to clean the house, the garden.

The search for new types of energy has developed many methodologies to substitute the old ones used in the last years, as the electricity and the conventional use of fossil fuel. In the last years were find out some ways to obtain energy from nature, as the solar energy, the wind energy and the one that uses the water, river force. Was even produced energy that use a strong chemistry reaction as the nuclear energy. All these energies have found its place in the actual world, but the biggest modern concern is to obtain an energy that not only can substitute the fossil source energy, more than it, the research departments around the world want to produce a less polluting energy, a clean, green chemistry. This idea is to produce a methodology that should not produce a large amount of residues and even more don't liberate toxic components at the atmosphere, diminishing the amount of pollutants in the air.
Research groups have found this kind of green chemistry, at the alternative renewable energy sources to produce fuel. These fuels can substitute the fossil ones that are difficult to find, to produce and that still can liberate many pollutants, as aromatics and derivatives of sulphur compounds. Two groups have achieved a certain prominence, attention, the methodologies to produce bioethanol and biodiesel.

\subsection{Biodiesel:}

The use of vegetable oils as an alternative fuel for diesel engine was discovered more than 100 years ago, in the Paris world exhibition in 1900, when Rudolph Diesel used peanut oil in an engine ignition [1]. This predicted saying, "The use of vegetable oils as fuel engine may be negligible in the present moment, but in the future may become so important as oil and coal as energy sources." The biodiesel term is a subject still under discussion. Some definitions consider biodiesel as a mixture of any vegetable oils with fuel, diesel and fossil derivative others consider the alkyl esters mixture from vegetable oils or animal fats with fossil fuels.

According to the Brazilian legislation, biodiesel is a mixture in different proportions of alkyl esters from vegetable oils or animal fats with fossil diesel. Under the chemical aspect biodiesel can be defined as alkyl esters derived from fatty acids obtained from oils, vegetables or animal fats, which suffering a chemical reaction, transesterification with short chain alcohols such as methanol and ethanol [2].

Transesterification: Chemical reaction between an ester (RCOOR ') and an alcohol ( $\mathrm{R} " \mathrm{COH})$ resulting in a

\footnotetext{
${ }^{\mathrm{a}}$ Corresponding author: mgfonseca $@$ inmetro.gov.br
} 
new ester (R"COOR') and an alcohol ( $\mathrm{RCOH})$. Illustrated in the below Figure 1:

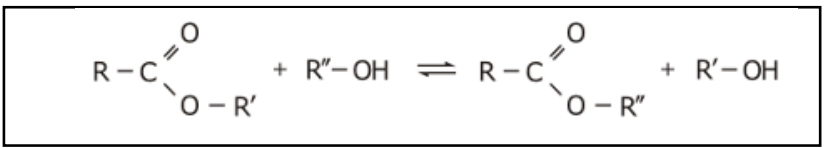

Figure 1: Transesterification reaction.

This reaction type used in biodiesel production is the reaction between the triglycerides, main components of vegetable oils and fats that react with short chain alcohols, methanol and ethanol, resulting methyl esters derived from fatty acids, with the byproduct glycerol formation.

In general terms these reactions take place under acid catalysis, base, enzyme or through the use of heterogeneous catalysts. Among the heterogeneous catalysts, we can highlight the use of zeolites [3], clays, ion exchange resins and oxides.

\subsection{Catalysts:}

Heterogeneous catalysts [4,5]has many advantages, one of them is the reaction work-up, i.e., post-treatment reaction, separation and purification steps, since these can be easily removed and the catalysts in general way, can be reused many times. Another interesting factor is the fact that this type of catalysis, difficult the formation of byproducts, such as saponification [6-8]. The greatest difficulty encountered in using this reaction type is directly related to problems in relation between the diffusion systems, oil / catalyst / methanol. Basic Catalysis [9], are procedures that use in general alkoxides of sodium and potassium, carbonates and hydroxides of these elements. Among these three groups it is found that alkoxides catalysts are financially unfavorable because they are more expensive but also difficult to handle because they are hygroscopic, and facilitate the achievement of side products such as derivatives of saponification, but have the advantage of carrying out the reactions in milder temperatures, produce high levels of esters derived from fatty acids and do not have corrosive properties as acid catalysts.

Inorganic catalysts, as sulfur and chlorides compounds are the most commonly used acid catalysts. This type of catalysis [10] has as main advantage the absence of products derived from saponification reactions, higher yields but has some disadvantages such as the fact that the reactions are performed in a highly corrosive and reactive post-treatment, where the medium, the rinse water should be neutralized.

A natural catalyst, the use of enzyme is a fourth class of compounds used to produce biodiesel [11]. In general its use is complicated by the fact that the enzyme generally are a specific material, and extremely expensive in relation to this type of reaction, are sensitive to the presence of methanol and ethanol, which causes deactivation of the same [12].

\subsection{Sources to obtain biodiesel:}

Sources used to biodiesel production are chosen according to the yield of oil by seed, by the quality of the obtained oil and the availability of the same in each region taking into account the relative low cost of production and favorable economies of scale. For example, the use of refined oil would not be favorable due to high production costs and low production scale, on the other hand the use of seeds, algae and fat have a low production cost and greater availability than refined oils or recycled, which is a favorable factor for the production of biodiesel from these elements.

An important factor for choosing a source of biodiesel production plants is the relationship between how much oil the seed produces and the yield of oil per hectare. Among the most studied are soybean, Babassu (Orbiginia sp.), Andiroba (Carapa guianensis), coconut, castor oil, fish oil, microalgae (Chorella vulgaris) [13], rice [4], wheat, tobacco [15], Jatropa Curcas [16], pequi (Caryocar sp.), Karanja (Pongamia glabra) [17], salmon [18], coffee beans [19], cooking oils [20], among others.

All biodiesel sources are chosen even according to the chemical composition of their fatty acids in relation to the size of their chains, unsaturation degree and the presence of other chemical functions, important factors that influence the biodiesel quality.

\subsection{Biofuel advantage:}

Biodiesel, an important renewable fuel, nowadays is considered an environmentally and socially favorable fuel by many factors. Its social impact is directed related to the rural areas job creation, in many different sectors, taking development since the beginning of biodiesel production process until to the most advanced techniques, the final stage production. These steps can be exemplified by the following examples: In the initial biodiesel production chain the stage of cultivation, agriculture development, followed by the industrial transformation of organic matter to biofuel to the advanced stage of research, where genetic engineering could lead to future energy sources that provide greater amounts of good quality oils, where the most desirable products are produced, thus performing a migration of various sectors of the major centers for the field, rural areas. This is environmentally friendly because seeds plantation reduce the amount of $\mathrm{CO}_{2}$ in the atmosphere through photosynthesis. Biodiesel decreases the release of gases that cause global warming, because when using biodiesel mixed with diesel causes a lower elimination of carbon dioxide and sulfur, produce less smoke and particulate emissions.

\subsection{Objective:}

This work is focused on a biodiesel short time stability study according to isoguide 35 . This study serves as basis for future biodiesel material reference obtaining and even as an important factor of an oil and methyl biodiesel data base from typical Brazilian seeds.

\subsection{Methodologies:}

-Oil extraction:

The seeds were dried in an oven at $50 \mathrm{C}$ for $24 \mathrm{~h}$. Then were conditioned in cartridge and the oil was extracted by hexane in a Soxhlet extracted apparatus. 
-Biodiesel synthesis:

The dried oilseed oil was reacted with the catalyst, potassium hydroxide dissolved in methanol for 45 minutes under heating of $50 \mathrm{C}$. The reaction medium was transferred to a separation funnel and left by 24 hours to separate the biodiesel from the glycerin, lower phase by decantation. After this step, the organic layer was washed three times with hydrochloric acid solution, followed by water until the neutral $\mathrm{pH}$. The obtained biodiesel was dried and characterized according to Brazilian legislation.

-Iodine index determination:

The iodine index was determined by titration according to EN 14111.

-Oxidative stability determination:

The oxidative stability was determined by Rancimat apparatus according to EN 14112.

- Short-term stability study:

The studied samples were separated in three groups. The first group contained the biodiesel under an oxidative atmosphere. The second group contained the blend biodiesel-diesel sample under an oxidative atmosphere. The third group contained diesel sample under oxidative atmosphere. All the three groups were studied, the first one, time zero was prepared and analyzed and the others were analyzed under heating at $50 \mathrm{C}$ during the following weeks. By the end of each week the samples were analyzed, obtaining the results for the total of four weeks. The short-term stability study was realized in accordance with the classical design method. In attempt to evaluate the samples stability were used two different methodologies, oxidative stability by Rancimat and Iodine index. The first one was maintained at the reference temperature of $\mathrm{T}=(20$ $\pm 2)^{\circ} \mathrm{C}$ during the whole time of the study ( 5 weeks). The second bottle was maintained at $\mathrm{T}=(50 \pm 2){ }^{\circ} \mathrm{C}$ for a period of 1 week, and the third one was maintained at $\mathrm{T}=(50 \pm 2)$ ${ }^{\circ} \mathrm{C}$ for 2 weeks, the same procedure was followed for all the samples until arrive the last one.

\subsection{Results:}

\begin{tabular}{|c|c|c|}
\hline Sample & $\begin{array}{c}\text { Result } \\
\text { (gI/ } / \mathbf{1 0 0 g})\end{array}$ & $\begin{array}{c}\text { Time } \\
\text { (weeks) }\end{array}$ \\
\hline $\begin{array}{c}\text { Soybean methyl } \\
\text { biodiesel }\end{array}$ & 128,8704 & 0 \\
\hline $\begin{array}{c}\text { Soybean methyl } \\
\text { biodiesel }\end{array}$ & 135,3154 & 1 \\
\hline $\begin{array}{c}\text { Soybean methyl } \\
\text { biodiesel }\end{array}$ & 135,2677 & 2 \\
\hline $\begin{array}{c}\text { Soybean methyl } \\
\text { biodiesel }\end{array}$ & 130,9165 & 4 \\
\hline $\begin{array}{c}\text { Soybean methyl } \\
\text { biodiesel }\end{array}$ & 131,6404 & 4 \\
\hline
\end{tabular}

Figure 1: Iodine index results from Soybean methyl biodiesel.

\begin{tabular}{|c|c|c|}
\hline Sample & $\begin{array}{c}\text { Result } \\
\left(\mathbf{g} \mathbf{I}_{\mathbf{2}} / \mathbf{1 0 0 g}\right)\end{array}$ & $\begin{array}{c}\text { Time } \\
\text { (weeks) }\end{array}$ \\
\hline Diesel & 16,0557 & 0 \\
\hline Diesel & 20,6531 & 1 \\
\hline Diesel & 20,7016 & 2 \\
\hline Diesel & 20,7675 & 3 \\
\hline Diesel & 17,9515 & 4 \\
\hline
\end{tabular}

Figure 2: Iodine index results from diesel.

\begin{tabular}{|c|c|c|}
\hline Sample & $\begin{array}{c}\text { Result } \\
\left(\mathbf{g I}_{\mathbf{2}} / \mathbf{1 0 0 g}\right)\end{array}$ & $\begin{array}{c}\text { Time } \\
\text { (weeks) }\end{array}$ \\
\hline Blend & 26,3859 & 0 \\
\hline Blend & 26,7224 & 1 \\
\hline Blend & 26,3516 & 2 \\
\hline Blend & 30,4170 & 3 \\
\hline Blend & 25,06 & 4 \\
\hline
\end{tabular}

Figure 3: Iodine index results from $5 \%$ soybean methyl biodiesel blend in diesel.

\begin{tabular}{|l|l|l|l|}
\hline Sample & uncertainty & average & P value \\
\hline $\begin{array}{l}\text { Methyl } \\
\text { soybean } \\
\text { biodiesel }\end{array}$ & 2,4018 & 132,4021 & 0,852202655 \\
\hline Diesel & 1,5624 & 19,2259 & 0,493052918 \\
\hline $\begin{array}{l}\text { Blend - 5\% } \\
\text { biodiesel in } \\
\text { diesel }\end{array}$ & 1,9347 & 26,9874 & 0,832653338 \\
\hline
\end{tabular}

Figure 4 : Results from the three analyzed compounds related to $\mathrm{P}$ value, average and uncertainty.

The obtained results show that the three analyzed compounds continue stable through the time. All the samples were analyzed from zero point, without have been heated until the last week study, after been heated at $50^{\circ} \mathrm{C}$ for fourth week . Initially the results don't show any tendency effect. Has been verified a linear result, where was observed a satisfactory result showing that this process don't degrade the biodiesel, continues stable, especially for this parameter. The evaluated samples were not degraded by time, neither were influenced by heating. Has been realized a F test: Variance regression analysis to verify the stability variation. (iso guide $35: 2006$ ).

\section{Oxidative stability by Rancimat}

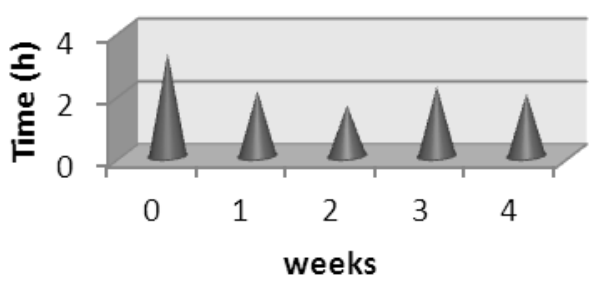

Figure 5 : Biodiesel analysis by oxidative stability by Rancimat. 
To maintain biodiesel stable for more time is necessary to use antioxidant. This type of compound is very sensible to heating, even to low heating $\left(50^{\circ} \mathrm{C}\right)$.

The obtained material can be stable through one month under $50^{\circ} \mathrm{C}$, just need to add a little amount of antioxidant to keep this one in a better condition.

\subsection{References}

[1] E. G. Shay, Biomass Bioenergy 4, (4), 227-242, (1993).

[2] A.C. Pinto, L.L.N. Guarieiro, M .J. C. Rezende, N. M. Ribeiro, E.A. Torres, A.W. Lopes, P.A.P. Pereira, J. B. Andrade, J. Braz. Chem. Soc. 16, 6B, 1313-1330, (2005).

[3] G. J. Suppes, M. A. Dasari, E. J. Doskocil, P. J. Mankidy, M. J. Goff, J. Appl. Catal,. A. 257, 213-223, (2004).

[4] L. Wang, J. Yang, Fuel 86 (3), 328-333, (2007).

[5] E. Leclercq, A. Finiels, C. Moreau, J. Am. Oil Chem. Soc. 78, 1161-1165, (2001).

[6] G. J. Suppes, K. Bockwinkel, S. Lucas, J. B. Botts, M. H. Mason, J. A. Heppert, J. AM. Oil Chem. Soc. 78, 2, 139-146, (2001).

[7] A.V. Tomasevic, S.S. Marinkovic, Fuel Process Technol:;81,1-6, (2003).

[8] S. Gryglewicz, Bioresour Technol, 70:249-253, (1999).

[9] W. Zhou, S.K. Konar, D.G.V. Boocock, J Am Oil Chem Soc 80, (4), 367-371, (2003).

[10] I.A.W. Mohamad, O.A.Ali, Bioresour Technol. 85, 225-256, (2002).

[11] H. Fukuda, A. Konda, H. Noda, J. Biosc. Bioeng. 92, 405-416, (2001).

[12] A. Salis, M. Pinna, M. Manduzzi, V. Solinas, J. Molec. Catal. B., Enzim. 54 (1), 19-26, (2008).

[13] X. Miao, Q. Wu, Bioresour. Technol. 97, 841-846, (2006).

[14] T. O. M. Silva, "Síntese e Caracterização de biocombustiveis obtidos a partir do arroz e seus derivados"; Porto Alegre, Pontifícia Universidade Católica do Rio Grande do Sul, 2008. 93p (Tese de dissertação de mestrado em Engenharia e Tecnologia de materiais).

[15] N. Usta, Biomass and Bioenergy 28, 77-86, (2005).

[16] H. J. Berchmans, S. Hirata, Bioresour. Technol. 99, 1716-1721, (2008).

[17]L. C. Meher, V. S. S. Dharmagada, S. N. Naik, Bioresour. Technol. 97 , 1392-1397, (2006)

[18] H. M. El-Mashad, R. Zhang, R. J. Avena-Bustillos, "A two steps process for biodiesel production from salmon oil”; Bisosys. Engin. 99, 220-227, (2008).

[19] R. R. S. Camargos, "Avaliação da viabilidade de se produzir biodiesel a partir de grãos de café defeituosos"; Belo Horizonte: Universidade Federal de Minas Gerais, (2005). 105 p. (Dissertação, Mestrado em Engenharia Química).

[20] P. R. Costa Neto, L. F. S. Rossi, G. F. Zagonel, L. P. Ramos, Química Nova, 23 (4), 531-537, (2000) 